$\mathrm{L}$

\title{
Enhancement of protease production by the optimization of Bacillus subtilis culture medium
}

\author{
Jee Yin Cheong, Muskhazli Mustafa*, Nor Azwady Abd. Aziz, Rusea Go and Azleen Ahmad Adli
}

Department of Biology, Faculty of Science, Universiti Putra Malaysia, 43400 UPM Serdang, Selangor, Malaysia. Email: muskhazli@science.upm.edu.my

Received 4 April 2012; Received in revised form 16 July 2012; Accepted 9 August 2012

\begin{abstract}
Aims: Traditionally, crustacean wastes have been managed by using acid and alkali which leads to major environmental issue. However, over the recent years microbial fermentation has gained its way whereby producing similar effects as chemical treatment and a higher quality product can be obtained. Extracellular protease from Bacillus subtilis was used further by optimizing its culture medium to enhance protease production.

Methodology and Results: The culture media was optimized with 4 various sources; Shrimp Crab Shell Powder (SCSP), nitrogen sources, inorganic salts, and carbon sources. It was found that culture media supplemented with $9 \%$ SCSP, $3 \%$ yeast extract, $1 \%$ sodium chloride and $9 \%$ glucose augmented protease activity up to $565.80 \pm 19.41 \mathrm{U} / \mathrm{mL}$ compared to the un-optimized media $(170.57 \pm 6.75 \mathrm{U} / \mathrm{mL})$. By using this optimized media, the ability and efficiency of $B$. subtilis in a period of 6 days was investigated whereby acid treated shrimp shells (ATSS) and raw shrimp shell powder (RSSP) were used in substitution of SCSP. In a period of 6 days, the protein content in both ATSS and RSSP was found to have been removed up to $60 \%$ and $42 \%$ respectively. However deproteinization was found to be more efficient in RSSP with the ratio of tyrosine to protein remained constantly high throughout the 6 days period.

Conclusion, significance and impact of study: A better, more efficient and environmental friendly method is continuously being improvised to manage shrimp wastes with the use of microbes.
\end{abstract}

Keywords: Bacillus subtilis, deproteinization, shrimp, fermentation

\section{INTRODUCTION}

The carapace, tail, and leg portions of crustacean are not being consumed and are removed during food processing. This waste gradually accounts up to approximately $50 \%$ of the harvested amount (Wang et al., 2007). The increasing amount of shrimp waste has resulted in environmental problem as natural degradation takes years to complete. Hence, attention should be given in managing the waste and ecosystem. These shrimp wastes fetch high economic value in the market. Shrimp waste mentioned has a high amount of chitin and pigments such as astaxanthin, beta-carotene and other carotenoids. Chitin and its derivatives holds great value as it is widely used in cosmetics, agriculture, biotechnology, water treatment and biomedical therapies (Stephen, 1991). Pigments such as astaxanthin and carotenoids are widely used in aquaculture feeds (Chien and Shiau, 2005), food industries as a supplement for human, pharmaceutical, cosmetics (Seki et al., 2001) and medical studies (Bhuvaneswari et al., 2010).
Commercially, shrimp shells and crustacean wastes are managed by treating them with strong acid and alkali to remove minerals and proteins respectively (Roberts, 2008). Nevertheless, the use of chemicals has eventually destroys the natural

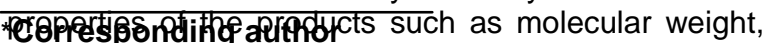
viscosity and degree of deacetylation of chitin (Sini et al., 2007). Besides, other value added products such as astaxanthin could not be recovered (Healy et al., 1994). These chemical treatment methods has brought hazard to the environment. Extra care has to be taken in disposing the wastewater as acid corrosion might take place. Moreover, chemical reactions are much difficult controlled and require desalting (Wang et al., 2006).

To overcome the problems caused by chemical treatments, various microorganisms (Wang and Yeh, 2006; Oh et al., 2007; Jo et al., 2008) and proteolytic enzymes (Sumantha et al., 2006) have been introduced. During fermentation with microbes, acid is produced and this accounts for the natural demineralization to take place while deproteinzation 
takes place by the activity of protease from the microbe (Sini et al., 2007). Oh et al. (2000) reported that when crustacean wastes were fermentated with Pseudomonas aeruginosa, deproteinization was recorded highest at $78 \%$. Microbes are ubiquitous, thus making them cheap and easy to obtain. Unlike chemicals, the usage of microbes is more environmental friendly. However, this method faces problems such as contamination and time consuming as deproteinization might take up to 7 days (Oh et al., 2000) or more (Sini et al., 2007) to complete.

Enzyme such as proteases, accounts for one of the most important enzymes in the enzyme market. Alkaline protease is much more dominating due to its primary applications as a cleaning additive in the detergent industry (Mukherjee et al., 2008). Neutral protease on the other hand is widely used in the study of deproteinization (Yang et al., 2000; Mukhtar and Haq, 2008). High protease yielding microbes includes species of Bacillus sp., Alcaligenes faecalis, Pseudomonas fluorescence, and Aeromonas hydrophilia. Among these bacteria, the most important group of bacteria used in the enzyme industry and has an effective proteolytic activity are of Bacillus sp. (Boominadhan et al., 2009).

The fact that the commercially available method releases hazards to the environment has thus brought to the attempt of using microbes to overcome this problem. In this study, Bacillus subtilis is used to deproteinize shrimp shells due to its high protease producing ability. We attempt to optimize the culture media for maximum protease production in $B$. subtilis; in addition to investigate the ability and efficiency of $B$. subtilis to deproteinize shrimp shells in a period of 6 days.

\section{MATERIALS AND METHODS}

\section{Materials and Microorganism}

Shrimp Crab Shell Flake (Sigma Co.) was blended into fine powder; Shrimp Crab Shell Powder (SCSP) while raw shrimp shells were obtained from the local wet market, cleaned (removal of gills and brain); thoroughly rinsed with tap water and oven dried at 50 ${ }^{\circ} \mathrm{C} \pm 2{ }^{\circ} \mathrm{C}$ for at least $24 \mathrm{~h}$ or until a constant weight was obtained. The dried raw shrimp shells were also blended into fine powder known as raw shrimp shell powder (RSSP). Part of the RSSP was treated with $2 \mathrm{~N}$ of hydrochloric acid (Yang et al., 2000) before oven dried at $50{ }^{\circ} \mathrm{C} \pm 2{ }^{\circ} \mathrm{C}$ for at least $24 \mathrm{~h}$ or until a constant weight was obtained and labelled as acid treated shrimp shells (ATSS).

Bacillus subtilis ATCC 14893 was obtained from the culture collections of Laboratory of Plant Systematic and Microbe, Department of Biology, Faculty of Science, University Putra Malaysia. The bacteria was maintained on nutrient slant agar and stored at room temperature $28^{\circ} \mathrm{C} \pm 2{ }^{\circ} \mathrm{C}$.

Determination of Protein Content in Shrimp Shells.
Protein content in shrimp shells was carried out according to Yang et al., (2000) with some modifications where RSSP was mixed with $2 \mathrm{~N}$ sodium hydroxide in a 1:10 ratio $(\mathrm{w} / \mathrm{v})$ to ensure complete reaction of RSSP with the alkali. The mixture was boiled at $100{ }^{\circ} \mathrm{C}$ for 30 min before centrifuging at 9000 $\mathrm{xg}$ for $2 \mathrm{~min}$. Finally, protein content in the supernatant was determined by the method of Bradford (1976) using Bio-Rad protein concentrate dye. Protein concentration was measured spectrophotometrically at $595 \mathrm{~nm}$ and bovine serum albumin was used as the standard.

\section{Culture Media Optimization}

Minimal Synthetic Media (MSM) containing 0.1\% (w/v) $\mathrm{K}_{2} \mathrm{HPO}_{4}$ and $0.05 \%(\mathrm{w} / \mathrm{v}) \mathrm{MgSO}_{4} \cdot 7 \mathrm{H}_{2} \mathrm{O}$ were mixed and used throughout the experiment. The culture conditions to be optimized were chosen and carried out as followed: (i) SCSP; (ii) nitrogen sources (ammonium nitrate, bacto-peptone, sodium nitrate and yeast extract); (iii) inorganic salts (calcium chloride, copper (II) sulphate, manganese sulphate and sodium chloride); and (iv) carbon sources (arabinose, glucose, and lactose). Each optimization was conducted in quintuplicate where the concentrations were set at 1 , $3,5,7$, and $9 \%(w / v)$ respectively. Optimization was conducted one at the time where for each element optimization, the optimum concentration determined for the previously tested element was added or weight was added into the MSM. Sources were chosen based on the highest protease activity obtained. All cultures were shaken at $180 \mathrm{rpm}$ at $30{ }^{\circ} \mathrm{C}$ for $48 \mathrm{~h}$ unless stated (Sini et al., 2007), pH was set at 7.0 (Yang et al., 2000). Cultures were harvested by centrifuging $8000 \mathrm{xg}$ for $20 \mathrm{~min}$ before filtering through a $0.2 \mu \mathrm{m}$ cellulose micro-filter and the supernatant was used for protease assay.

\section{Deproteinization of Shrimp Shells}

The ability and efficiency of $B$. subtilis to deproteinize shrimp shells was tested in a period of 6 days. For this RSSP and ATSS were used to substitute SCSP, respectively in the optimized media. Cultures were left to incubate for 6 days in an incubated shaker; where individual cultures were harvested every 2 days for protease and protein assay. All the culture conditions used were the same.

\section{Protease assay}

The activity of protease was measured by mixing 150 $\mu \mathrm{L}$ of the enzyme with $750 \mu \mathrm{L}$ of substrate (containing $10 \mathrm{mg} / \mathrm{mL}$ of casein in $200 \mathrm{mM}$ of sodium phosphate buffer, $\mathrm{pH} 7.4$ and $5 \mathrm{mM}$ phenylmethylsulphonyl fluoride, PMSF) before incubated in a water bath at 37 ${ }^{\circ} \mathrm{C}$ for $30 \mathrm{~min}$. Enzyme reaction was terminated by adding $150 \mu \mathrm{L}$ of $10 \%$ trichloroacetic acid (TCA), $6.1 \mathrm{~N}$ in an ice bath for $15 \mathrm{~min}$. The mixture was centrifuged 
at $8000 \mathrm{xg}$ for $5 \mathrm{~min}$ to precipitate un-degraded protein. The supernatant $(750 \mu \mathrm{L})$ was added with $3.75 \mu \mathrm{L}$ of $0.5 \mathrm{M}$ sodium carbonate and $750 \mu \mathrm{L}$ FolinCiocalteau reagent (threefold diluted with distilled water) before incubating in dark for $2 \mathrm{~h}$. The mixture was measured as suggested by Ferrero (2000) with tyrosine as the reference compound. One unit of protease activity was expressed as the amount of enzyme required to release $1 \mu \mathrm{mol}$ of tyrosine in 660 $\mathrm{nm}$.

\section{Statistical Analysis}

All the data collected was analysed using ANOVA where the confidence level was set at $95 \%$. Any significance difference $(p<0.05)$ was analyzed using Turkey test. The data was analyzed using SPSS program version 16.0.

\section{RESULTS AND DISCUSSIONS}

\section{Optimization of the culture media}

Shrimp crab shell powder was used to test the ability of $B$. subtilis in producing extracellular protease. Increasing protease production in $B$. subtilis is vital for the deproteinization of shrimp shells. Various concentrations of SCSP were brought into test and it was found that maximum protease activity was obtained when the concentration was 9\% (w/v) (Figure 1). Further investigation on the concentration was not done due to the increasing amount of SCSP (solid) which influences the fermentation system where the culture media could not support the amount of solid present and affects the shaking of the culture media. Protease activity was boosted up to $87 \%$ with increasing SCSP supply. Increasing the concentration of SCSP increases the activity of protease linearly with a rate of $34.97 \mathrm{U} / \mathrm{mL}$ where this rate was not reported in most of the studies done. Though protease activity was recorded higher in 3\% than in $5 \%(\mathrm{w} / \mathrm{v})$ of SCSP; nevertheless, statistical results indicated that there were no significance differences $(p<0.05)$ observed between these two concentrations. This significant increase in protease activity shows the presence of extracellular protease in $B$. subtilis and was enhanced by the increasing SCSP supply.

According to Wang and Yeh (2006), the best inducer for protease would be a carbon/nitrogen source with a protein to chitin ratio of $1: 1$ rather than the carbon/nitrogen source with only protein but no chitin or a source with a high protein ratio. The protein: chitin: mineral content in SCSP was found to be in the ratio of $29 \%$ : $31 \%$ : $40 \%$ compared to squid pen powder, 61\%: 38\%: 1\% (Wang et al., 2007). However, the use of substrate with higher protein content (i.e. squid pen powder) will not always give high protease activity due to that the protein and chitin has to exist together either by chemical bonded or physical barrier such as counter changed between inner and outer layers to be a better protease inducer (Wang and Yeh,
2006). Hence, this has brought to the suggested chitin to protein ratio to be $1: 1$ as stated above. Meanwhile, Wang et al. (2007) reported that $1 \%$ of squid pen powder has only managed to produce $0.015 \mathrm{U} / \mathrm{mL}$ of protease activity in Vibrio fluvialis TKU005, while in the present study, $1 \%$ of SCSP gave an enzyme activity of $22.71 \pm 5.7 \mathrm{U} / \mathrm{mL}$ which was much higher than that of squid pen powder. Therefore this has proven that to induce protease production, the protein to chitin ratio in the inducing substrates should not be too big and SCSP was just nice as an inducer. Thus, the finding of this study supports the previously suggested SCSP as one of the best inducer compared to the other available sources such as squid pen powder, shrimp shell powder, crab shell powder, casein and etc. In addition, much studies conducted has adapted SCSP as the inducer of protease (Yang et al., 2000; Wang and Hwang, 2001; Liang et al., 2006).

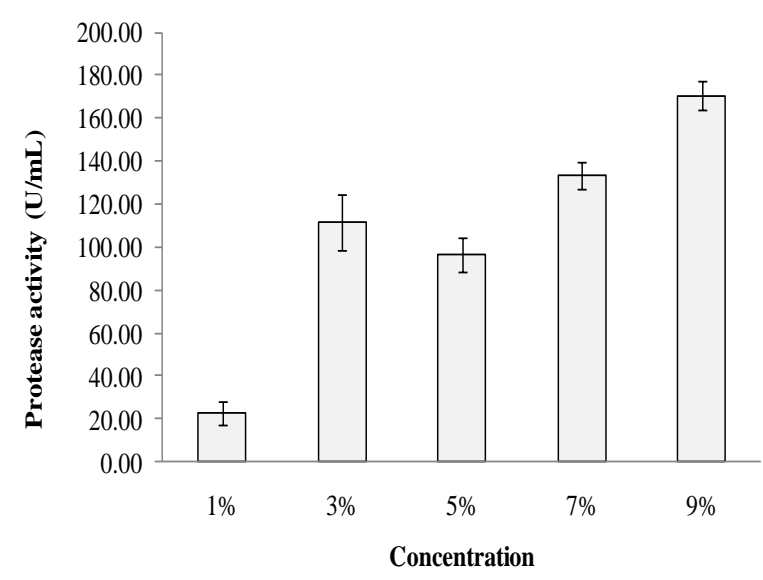

Figure 1: Protease activity of different concentration of shrimp crab shell powder.

With the rate of protease activity at $34.97 \mathrm{U} / \mathrm{mL}, B$ subtilis ATCC 14893 can be considered as good deproteinization agent. Bacillus subtilis ATCC 14893 works best under $9 \%(\mathrm{w} / \mathrm{v})$ SCSP while study by Oh et al., (2000) demonstrated that Pseudomonas aeruginosa prefers a concentration of $5 \%$ SCSP. Meanwhile Yang et al., (2000) showed that B. subtilis $Y-108$ favours $7 \%$ SCSP. The difference in the preferred SCSP concentration differs within strains and species as different strain and species has different ability of utilizing the supplied SCSP.

In order to study the effect of nitrogen sources on protease production, growth was carried out in a medium containing only $9 \%(\mathrm{w} / \mathrm{v})$ SCSP and MSM where it is gradually being added with different nitrogen sources. In Figure 2, protease production was slightly enhanced by the addition of ammonium nitrate and sodium nitrate into the medium. However, when the media was supplied with yeast extract, protease activity recorded an increase from $170.57 \pm 6.75 \mathrm{U} / \mathrm{mL}$ (control) to $253.143 \pm 56.81 \mathrm{U} / \mathrm{mL}$. When the 
Mal. J. Microbiol. Vol 9(1) 2013, pp. 43-50

concentrations of yeast extract was further being investigated, it was found that $3 \%(\mathrm{w} / \mathrm{v})$ yeast extract was the most effective concentration to enhance protease production where an increase of $33 \%$ in enzyme activity was observed compared to the control.

Protease activity was greatly enhanced with the presence of complex carbon and nitrogen rather than simple sugars (Guangrong et al., 2008). In the present study, yeast extract, a complex nitrogen source was found to be the optimum nitrogen source for protease production by $B$. subtilis ATCC 14893 and similar results were reported by Guangrong et al. (2008) and Prakasham et al. (2006). Meanwhile in the study by Boominadhan et al. (2009) on 4 types of Bacillus species; $B$. subtilis, $B$. amyloliquefaciens, $B$. megaterium and $B$. licheniformis by using casein as substrate and yeast extract as nitrogen source, protease activity was recorded as two fold higher that the current study $(540.12 \pm 1.12 \mathrm{U} / \mathrm{mL})$. This showed that different combinations between the inducer and the enhancer gave a different value in enzyme activity. Nevertheless, the process of optimization and the requirement for maximum enzyme production is unique to every organism.

In Figure 3, inorganic salts were put into test and none of the sources enhanced protease production compared to control (a mixture of MSM, 9\% SCSP and $3 \%$ yeast extract) except sodium chloride. The use of $1 \%(\mathrm{w} / \mathrm{v})$ and $7 \%(\mathrm{w} / \mathrm{v})$ of sodium chloride gave the highest protease activity of $282.69 \pm 8.15 \mathrm{U} / \mathrm{mL}$ and $286.11 \pm 11.80 \mathrm{U} / \mathrm{mL}$, respectively. However, due to no significance difference was detected between these two concentrations $(p<0.05), 1 \%$ was chosen as to be added into the optimizing media where significant increase in protease activity was noted (data not shown).

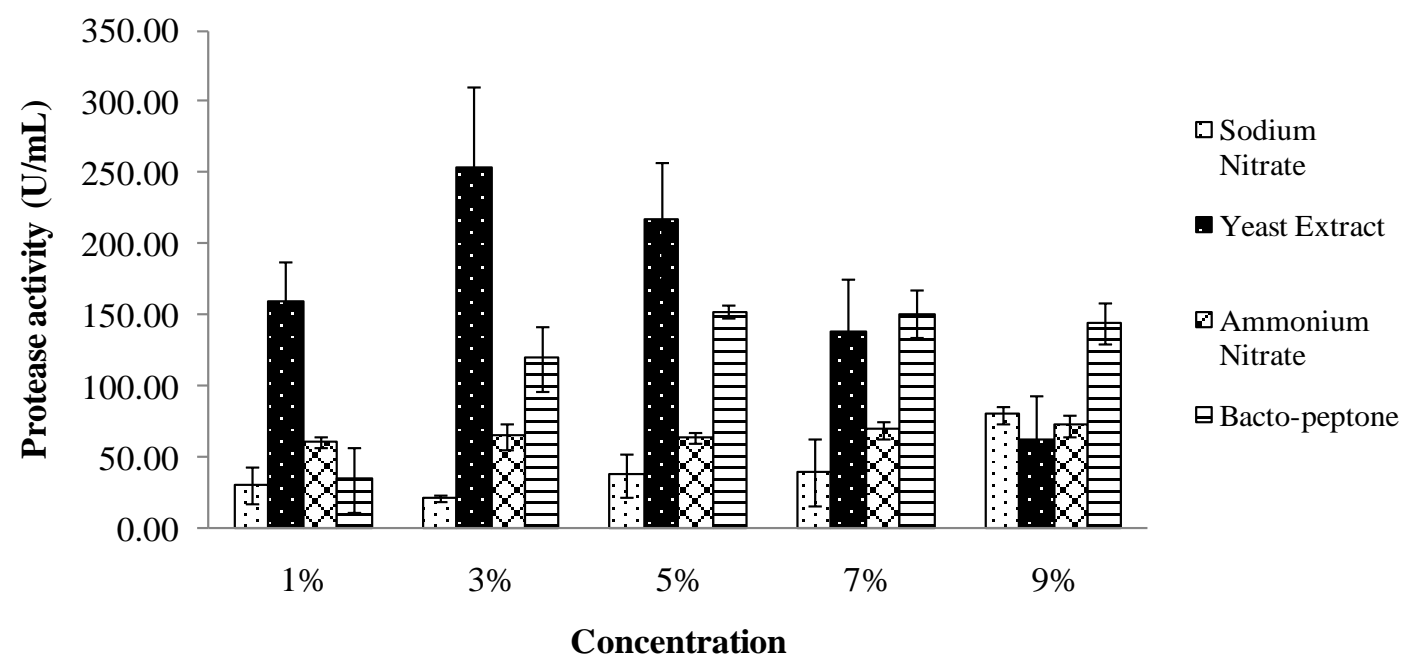

Figure 2: Protease activity of different types of nitrogen sources in different concentrations.

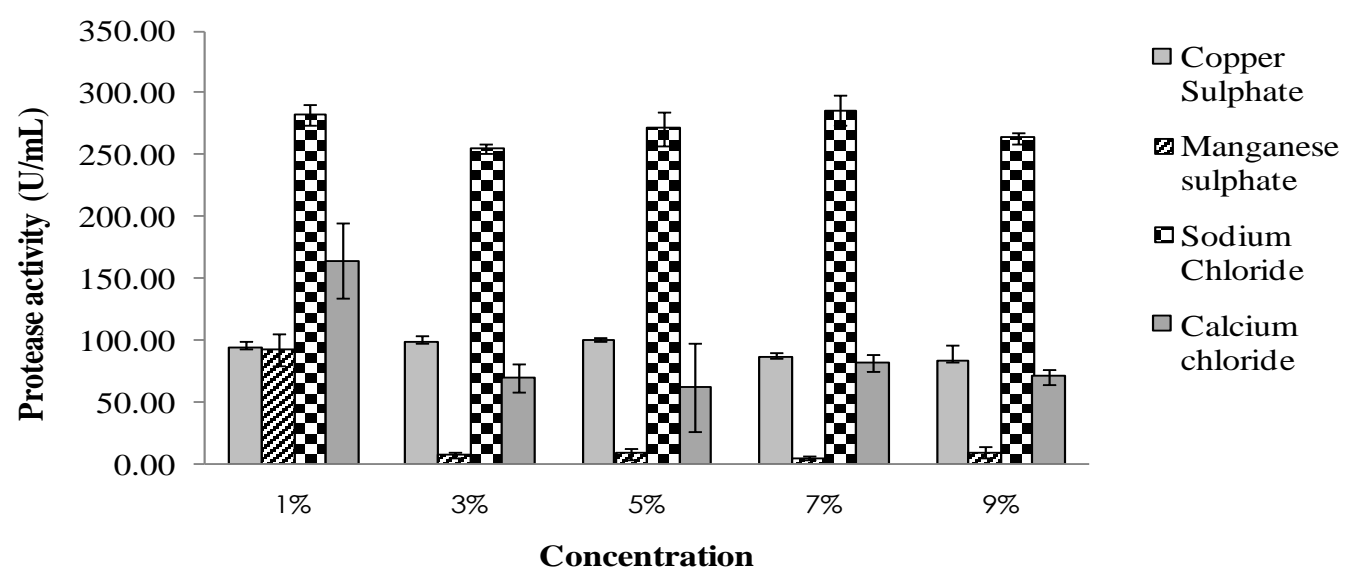

Figure 3: Protease activity of different types of inorganic sources in different concentrations. 
The addition of sodium chloride to the culture with Saccharomyces cerevisiae was found to give an increase in cell metabolism when the $k_{m}$ values of carbon dioxide released recorded was found to be 2.0 $\mu \mathrm{mol} / \mathrm{mg} / \mathrm{h}$; while without sodium chloride, 0.2 $\mu \mathrm{mol} / \mathrm{mg} / \mathrm{h}$ was recorded (Watson, 1970). In the present study, the addition of $1 \%(\mathrm{w} / \mathrm{v})$ of sodium chloride increases $29.55 \mathrm{U} / \mathrm{mL}$ of enzyme activity, thus shows an increase in growth and cell metabolism. Nevertheless high concentration of sodium chloride inhibited growth (Gibson and Roberts., 1986; Neysens et al., 2003; Hajmeer et al., 2006) where this technique is commonly used in preservation of food and varies with microorganisms.

The addition of other inorganic sources did not boost up protease activity significantly; in fact protease activity was recorded very low. The reason for the low enzyme activity recorded in this study might due to the fact that calcium and magnesium partially inhibits enzyme activity while copper acts as an enzyme inhibitor (Wang et al., 2009).

The secretion of protease was augmented with the introduction of carbon sources in the media where protease activity varied markedly from $35.74 \mathrm{U} / \mathrm{mL}$ to $565.80 \mathrm{U} / \mathrm{mL}$ in Figure 4. A very low protease production was detected when low concentration of arabinose, glucose and lactose was used as the carbon source. Nevertheless, enzymatic activity was stimulated enormously by the increasing concentration of these carbon sources especially glucose. As the concentration of glucose increases, protease production increased with a rate of $111.14 \mathrm{U} / \mathrm{mL}$. Thus, glucose was found to be the best substrate to stimulate protease production where $9 \%(\mathrm{w} / \mathrm{v})$ of glucose gave a maximum protease activity of 565.80 $\mathrm{U} / \mathrm{mL}$.

As previously explained, the combination of complex carbon and nitrogen sources enhances protease activity. Catabolic repression was significant under low supply of glucose $(1 \%$ and $3 \%)$ where protease activity was recorded $127.37 \pm 38.93 \mathrm{U} / \mathrm{mL}$ and $234.34 \pm 35.52 \mathrm{U} / \mathrm{mL}$ respectively which was lower than the control ( $9 \%$ SCSP, $3 \%$ yeast extract, $1 \%$ sodium chloride in MSM). However under high concentrations (5\%-9\%) catabolic repression was repressed as high protease activity was recorded high; between the range of $382.85-565.80 \mathrm{U} / \mathrm{mL}$. Despite of its catabolic repression, glucose being a simple sugar could be a better growth substance for bacteria as it is easy to be metabolised (De Azeredo et al., 2004; Guangrong et al., 2008). The present study is supported by Nadeem et al., (2008) where glucose was found to be the best source for $B$. licheniformis $N$ 2 to produce protease where an increase in protease production was a result of the addition of glucose.

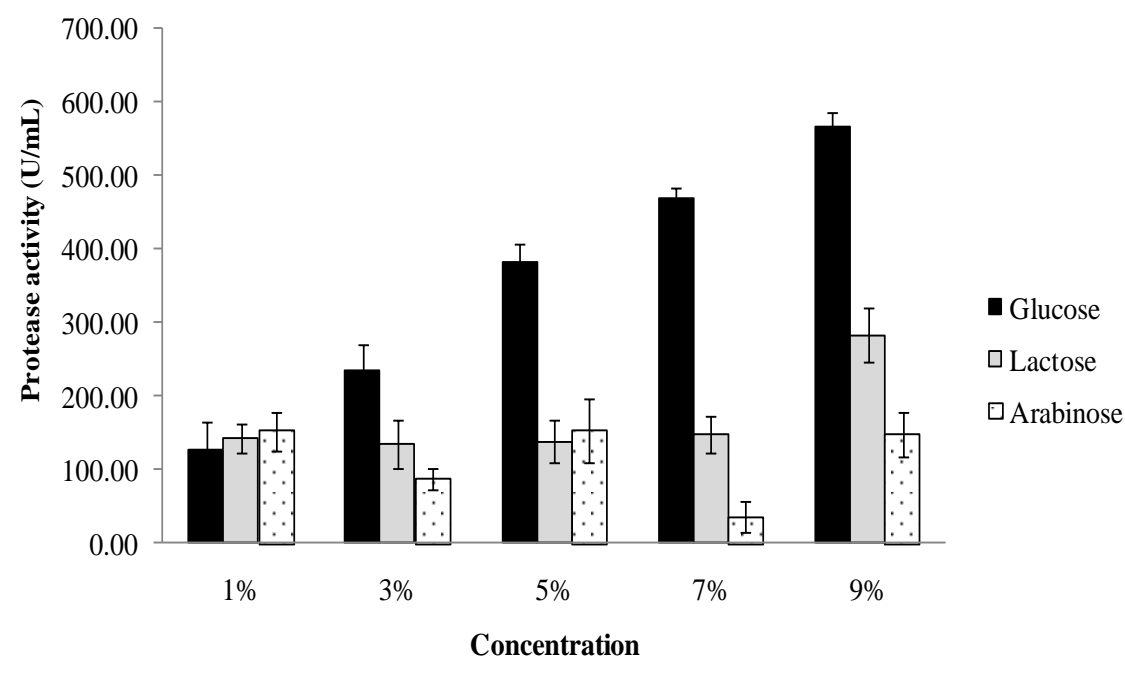

Figure 4 : Protease activity of various carbon sources in various concentrations.

\section{Comparisons between shrimp shells and SCSP}

The optimized culture conditions were found to be as in Table 1. Since the optimized media has given a dramatic increase in protease activity, $70 \%$ compared to the control, the same optimized media was used on RSSP to test the effectiveness of deproteinization by $B$. subtilis. All the conditions used in the experiment were the same. After 2 days of fermentation, protease activity of RSSP recorded an increase of $37 \%$ compare to optimized media with SCSP (Table 2). Meanwhile shrimp shells fermented in an un-optimized media recorded a protease activity was $158.13 \pm$ $38.11 \mathrm{U} / \mathrm{mL}$; compared to the control un-optimized media with SCSP, $170.57 \pm 6.75 \mathrm{U} / \mathrm{mL}$ only a slight difference was recorded. As supported by Wang et al., (2006), the protein/chitin/mineral ratio for shrimp shell 
Mal. J. Microbiol. Vol 9(1) 2013, pp. 43-50

was $48 \%$ : $38 \%$ : $14 \%$ where this ratio is a suitable ratio to induce protease production as mentioned above.

Table 1: The optimum culture media content and culture conditions determined for inducing protease activity in Bacillus subtilis ATCC 14893.

\begin{tabular}{ll}
\hline \multicolumn{2}{l}{ Optimized culture media } \\
\hline SCSP & $9 \%$ \\
$\mathrm{~K}_{2} \mathrm{HPO}_{4}$ & $0.1 \%$ \\
$\mathrm{MgSO}_{4} \cdot 7 \mathrm{H}_{2} \mathrm{O}$ & $0.05 \%$ \\
Yeast extract & $3 \%$ \\
Sodium chloride & $1 \%$ \\
Glucose & $9 \%$ \\
& \\
Culture condition & \\
Temperature & $30{ }^{\circ} \mathrm{C}$ \\
Time & 2 days \\
Volume & $10 \mathrm{~mL}$ \\
pH & 7.0 \\
\hline
\end{tabular}

Deproteinization of shrimp shell by $B$. subtilis using the optimized media was almost two fold higher compared to SCSP (Table 2). In the production of SCSP, the shrimp crab shell has been subjected to Maillard reaction (Wang and Chio, 1998) where the shells were cooked and dried under high temperature. This process has changed and destroyed most of the primary protein structure present (Wang and Chio 1998). Furthermore, Maillard reaction has caused the proteins to be resistant against protease treatment $(\mathrm{Oh}$ et al., 2000) and thus lowering the protease activity. Meanwhile in RSSP, shells are not processed the same way as SCSP. Natural cleaning and drying process retains most of the protein's primary structure and this leads to a more effective deproteinization.

Table 2 : Comparison between optimized condition and non-optimized condition

\begin{tabular}{lc}
\hline Treatment & Protease activity $(\mathrm{U} / \mathrm{mL})$ \\
\hline $\begin{array}{l}\text { Optimized media with } \\
\text { shrimp shells }\end{array}$ & $904.91 \pm 80.095^{\mathrm{a}}$ \\
$\begin{array}{l}\text { Optimized media with } \\
\text { SCSP }\end{array}$ & $565.80 \pm 19.41^{\mathrm{b}}$ \\
MSM + Shrimp shells & $158.93 \pm 38.10^{\mathrm{C}}$ \\
MSM + SCSP & $170.57 \pm 6.75^{\mathrm{C}}$
\end{tabular}

Note: Different superscript denotes that there is significance difference $(p<0.05)$

\section{Deproteinization of shrimp shells}

Deproteinization of shrimp shells was brought about by the neutral protease produced by $B$. subtilis ATCC 14893. Considering the ability to deproteinize shrimp shells, deproteinization with $B$. subtilis was carried out for a period of 6 days using RSSP and ATSS (demineralised).

During the first two days of fermentation, protein removal was only recorded as $34 \%$ and $33 \%$ for ATSS and RSSP respectively (Figure 5). However at the end of the sixth day of fermentation, protein removal has arisen to $60 \%$ in ATSS and $42 \%$ in RSSP. The demineralized shells gave more effective protein removal. Treating the shrimp shells with hydrochloric acid resulted in the removal of minerals from the shells where almost $99 \%$ of the calcium present in the shells was removed during the process of demineralization (Giyose et al., 2009). Though treating the shells with acid eased deproteinization, it is however less environmental friendly.

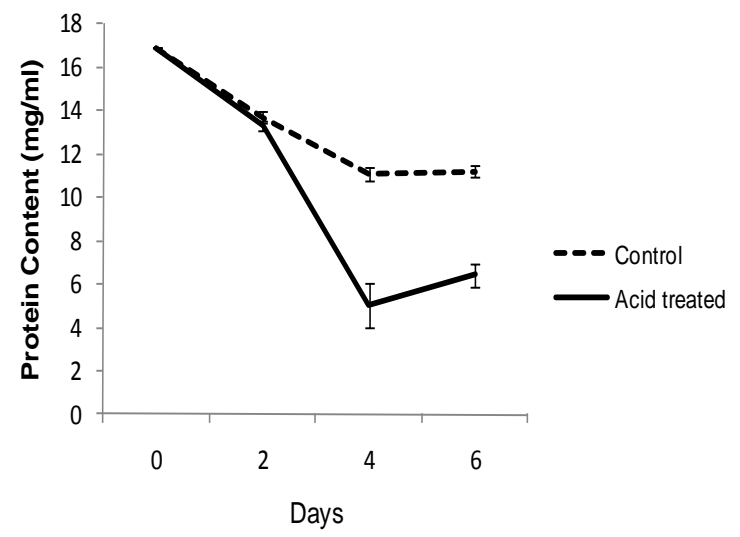

Figure 5: Amount of protein content left in shrimp shells in a period of 6 days.

It is obvious that protein removal was far more successful in ATSS. However when the effectiveness of deproteinization was investigated, it was found that the RSSP was more efficient in deproteinization (Figure 6). Even though, the rate of deproteinization was found to be higher in ATSS than RSSP with a value of $58.4 \mathrm{U} / \mathrm{mL}$ and $41.2 \mathrm{U} / \mathrm{mL}$, respectively, the higher deproteinizing rate in ATSS was probably due to the acid treatment which has removed almost $99 \%$ of the minerals present especially calcium as mentioned above. The effectiveness of deproteinization can be observed through the amount of tyrosine per protein produced and in our study; the amount of tyrosine per protein was found to be higher in RSSP than ATSS for all the 6 days recorded.

Chemical treated demineralization which exposes the proteins present might have given an advantage to a higher deproteinization rate but a lower efficiency of deproteinization due the destruction of many proteins and chitin present (Wang and Chio, 1998). Hydrolysis of the protein to amino acids has been carried out by treatment with acid (Dreze and 
Reith, 1956 cited by Tsugita and Scheffler, 1982). Hydrochloric acid causes the peptide bond to lyse in the shrimp shells, resulting in the demineralized shells having loosened protein bonds and destructed protein structures which lead to a higher deproteinizing rate (Tsugita and Scheffler, 1982).

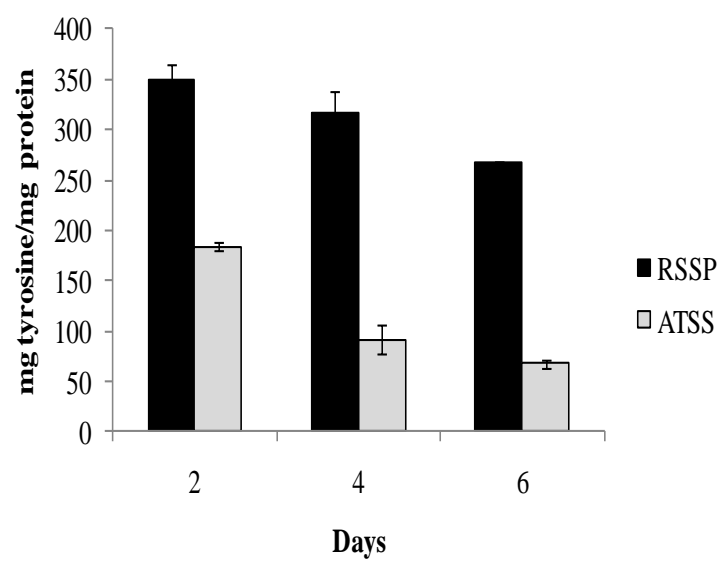

Figure 6: Amount of tyrosine per protein in a period of 6 days.

As the fermentation time increases, the amount of tyrosine per protein starts to decrease. Similar pattern was also reported by Sini et al., (2007) where this decrease was perhaps caused by the decreasing amount of protein which eventually leads to a decrease in protease production as the proteins are being used up by the $B$. subtilis in metabolism.

Generally, fermentation with microbes produces acid which degrades the available calcium in shrimp shells (Sini et al., 2007) where natural demineralization takes place. Acid released from the result of microbe fermentation is more environmental friendly compared to the synthetic acid used. Though protein removal was found to be better in ATSS, however, much of the protein structures have been destroyed by acid which leads to a lower quality of protein present. Meanwhile fermentation with $B$. subtilis resulted in a slightly lower protein removal but a higher quality of protein was maintained.

Further study can be done on the recovery of substances such as chitin, chitosan, pigments, and etc. with the processed shrimp waste. As shrimp waste contains mainly protein tissues, thus the removal of the protein tissues by microbial fermentation eases the recovery of substances.

\section{CONCLUSION}

Enhancing the protease produced by $B$. subtilis was done by the process of optimization where the optimized culture media was found to be $9 \%(w / v)$ of SCSP, $3 \%(\mathrm{w} / \mathrm{v})$ of yeast extract, $1 \%(\mathrm{w} / \mathrm{v})$ of sodium chloride, and $9 \%(\mathrm{w} / \mathrm{v})$ of glucose. This culture media boosted up protease activity from $170.57 \pm 6.75 \mathrm{U} / \mathrm{mL}$ to $565.80 \pm 19.41 \mathrm{U} / \mathrm{mL}$. Meanwhile the ability and effectiveness of $B$. subtilis in deproteinization was tested in a 6 day fermentation period where ATSS deproteinized $60 \%$ protein from the shells compared to bacteria fermentation which removed only $42 \%$. However, most of the proteins structures present in ATSS were destroyed leading it to be less efficient in deproteinization.

\section{ACKNOWLEDGEMENT}

We would like to thank University Putra Malaysia for their financial support through Research University Grant Scheme Grant no. 05-01-11-1235RU and all the staffs of Plant Systematic and Microbe Laboratory, Biology Department, University of Putra Malaysia for all their efforts.

\section{REFERENCES}

Bhuvaneswari, S., Arunkumar, E., Viswanathan, P. and Anuradha, C. V. (2010). Astaxanthin restricts weight gain, promotes insulin sensitivity and curtails fatty liver disease in mice fed a obesity-promoting diet. Process Biochemistry 45, 1406-1414.

Boominadhan, U., Rajakumar, R., Sivakumaar, P. K. V. and Joe, M. M. (2009). Optimization of protease enzyme production using Bacillus sp. isolated from different wastes. Botany Research International 2(2), 83-87.

Bradford, M. M. (1976). Rapid and sensitive method for the quantitation of microgram quantities of protein utilizing the principle of protein-dye binding. Analytical Biochemistry 72, 248-254.

Chein, Y. H. and Shiau, W. C. (2005). The effects of dietary supplementation of algae and synthetic astaxanthin on body astaxanthin, survival, growth and low dissolved oxygen stress resistance of kuruma prawn, Marsupenaus japonicas Bate. Journal of Experimental Marine Biology and Ecology 318, 201-211.

De Arezedo, L. A. I., Freire, D. M. G., Soares, R. M. A., Leite, S. G. F. and Coelho, R. R. R. (2004). Production and partial characterization of thermophilic proteases from Streptomyces sp. isolated from Brazilian cerrado soil. Enzyme and Microbial Technology 34, 354-358.

Ferrero, M. A. (2000). Protein hydrolysis. Food Microbiology Protocols 14, 227-232.

Gibson, A. M. and Roberts, T. A. (1986). The effect of $\mathrm{pH}$, sodium chloride, sodium nitrite and storage temperature on the growth of Clostridium perfringens and faecal streptococci in laboratory media. International Journal of Food Microbiology 3, 195-210.

Giyose, N. Y., Mazomba, N. T. and Mabinya, L. V. (2009). Evaluation of protease produced by Erwinia chrysanthemi for the deproteinization of crustacean waste in a chitin production process. African Journal of Biotechnology 9 (5), 707-711. 
Guangrong, H., Dehui, D., Weilian, H. and Jiaxin, J. (2008). Optimization of medium composition for thermostable protease production by Bacillus sp. HS08 with a statistical method. African Journal of Biotechnology 7, 1115-1122.

Hajmeer, M., Ceylan, E., Marsden, J. L. and Daniel Fung, Y. C. (2006). Impact of sodium chloride on Escherichia coli O157:H7 and Staphylococcus aureus analysed using transmission electron microscopy. Food Microbiology 23, 446-452.

Healy, M. G., Romo, C. R. and Bustos, R. (1994). Bioconversion of marine crustacean. Resources, Conservation and Recycling 11, 139-147.

Jo, G. H., Ju, W. T. and Park, R. D. (2008). Biological production of chitobiose from crab shell waste by microbial fermentation. Journal of Biotechnology 136: 467.

Liang T. W., Lin J. J., Yen Y. H., Wang C. L. and Wang S. L. (2006). Purification and characterization of a protease extracellularly produced by Monascus purpureus CCRC31499 in a shrimp and crab shell powder medium. Enzyme and Microbial Technology 38, 74-80.

Mukherjee A. K., Adhikari H. and Rai S. K. (2008). Production of alkaline protease by $a$ thermophilic Bacillus subtilis under solid strate fermentation (SSF) condition using Imperate cylindrica grass and potato peel as low cost medium: Characterization and application of enzyme in detergent formulation. Biochemical Engineering Journal 39,353-361.

Mukhtar H. and Haq I. U., (2008). Production of alkaline protease by Bacillus subtilis and its application as a depilating agent in leather processing. Pakistan Journal of Botany 40(4), 1673-1679.

Nadeem, M., Qazi, J. I., Baig, S. and Syed, Q. U. A. (2008). Effect of medium composition on commercially important alkaline protease production by Bacillus licheniformis N-2. Food Technology and Biotechnology 46(4), 388-394.

Neysens, P., Messens, W. and De Vuyst, L. (2003). Effect of sodium chloride on growth and bacteriocin production by Lactobacillus amylovorus DCE 471. International Journal of Food Microbiology 88, 29-39.

Oh, T. K., Kim, Y. J., Nguyen, V. N., Jung, W. J., and Park, D. R. (2007). Demineralization of crab waste by Pseudomonas aeruginosa F722. Process Biochemistry 42, 1069-1074.

Oh, Y. S., Shih, L. I., Tzeng, Y. M. and Wang, S. L. (2000). Protease produced by Pseudomonas aeruginosa $\mathrm{K}-187$ and its application in the deproteinization of shrimp and crab shell wastes. Enzyme and Microbial Technology 27, 3-10.

Prakasham, R. S., Shuba Rao, C. and Sarma, P. N. (2006). Green gram husk-an inexpensive substrate for alkaline protease production by
Bacillus sp. in solid-state fermentation. Bioresource Technology 97, 1449-1454.

Roberts, G. A. F. (2008). Thirty years of progress in chitin and chitosan. Progress on Chemistry and Application of Chitin 13, 7-15.

Seki, T., Sueki, H., Kohno, H., Suganuma, K. and Yamashita, E. (2001). Effects of astaxanthin from haematoccocus pluvalis on human skin. Fragrance Journal 12, 98-103.

Sini, T. K., Santhosh, S. and Mathew, P. T. (2007). Study on the production of chitin and chitosan from shrimp shell by using Bacillus subtilis fermentation. Carbohydrate Research 342, 2423-2429.

Stephen, N. (1991). Life after death for empty shells: Crustacean fisheries create a mountain of waste shells, made of a strong natural polymer, chitin. Now chemists are helping to put this waste to some surprising uses. New Scientist 1755.

Sumantha, A., Larroche, C. and Pandey, A. (2006). Microbiology and industrial biotechnology of food-grade proteases: A perspective. Food Technology and Biotechnology 44, 211-220.

Tsugita, A. and Scheffler, J. (1982). A rapid method for acid hydrolysis of protein with a mixture of trifluoroacetic acid and hydrochloric acid. European Journal of Biochemistry 124, 585588.

Wang, S. L. and Chio, S. H. (1998). Deproteinization of shrimp and crab shell with the protease of Peudomonas aeruginosa K-187. Enzyme and Microbial Technology 22, 629-633.

Wang S. L., and Hwang J. R. (2001). Microbial reclamation of shellfish wastes for the production of chitinases. Enzyme and Microbial Technology. 28, 376-382.

Wang, S. L. and Yeh, P. L. (2006). Production of a surfactant- and solvent-stable alkaliphilic protease by bioconversion of shrimp shell wastes fermented by Bacillus subtilis TKU007. Process Biochemistry 41, 1545-1552.

Wang, S. L., Chio, Y. H., Yen, Y. H. and Wang, C. L. (2007). Two novel surfactant-stable alkaline proteases from Vibrio fluvalis TKU005 and their applications. Enzyme and Microbial Technology 40, 1213-1220.

Wang, S. L., Yang, C. W., Liang, T. W., Peng, J. H. and Wang, C. L. (2009). Degradation of chitin and production of bioactive materials by bioconversion of squid pens. Carbohydrate Polymers 78, 205-212.

Watson, T. G. (1970). Effects of Sodium chloride on steady-state growth and metabolism of Saccharomyces cerevisiae. Journal of General Microbiology 64, 91-94.

Yang, J. K., Shih, I. L., Tzeng, Y. M. and Wang, S. L. (2000). Production and Purification of protease from a Bacillus subtilis that can deproteinize crustacean wastes. Enzyme and Microbial Technology 26, 406-413. 